\title{
Motivational Macro-Strategies Used to Teach English at CAMASC, SDIF shelter, Tapachula
}

DOI: $10.46932 / \mathrm{sfjdv} 3 \mathrm{n} 1-033$

Received in: Dec 30st, 2021

Accepted in: Jan 1th, 2022

\section{Dra. Gloria Amelia Gutú Moguel}

Profesora de Inglés de la Universidad Autónoma de Chiapas, México.

Actualmente es Coordinadora de Investigación y Posgrado y Coordinadora de Diseño del programa de la Maestría en la Enseñanza del Inglés de la Escuela de Lenguas, Tapachula.

E-mail: gloria.gutu@unach.mx,gloria_gutu@ hotmail.com

Eric Iván Aguilar Salvador

Profesor en el Colegio Antar y es Profesor independiente.

E-mail: eric_iv96@hotmail.com

José Antonio Aguilar Salvador

estudiante universitario y profesor independiente.

E-mail: antonio99_16@hotmail.com

Mtra. Angélica Patrícia Córdoba Meza

Profesora de Inglés de la Escuela de Lenguas de la Universidad Autónoma de Chiapas.

E-mail: angelica.cordoba@unach.mx

\section{Dra. Antonia Jiménez Alba}

Profesora de Francés de la Escuela de Lenguas, Tapachula en la Universidad Autónoma de Chiapas.

E-mail: antonia.jimenez@unach.mx

\section{Dra. Ana Rosa Núñez Serrano}

Profesora en la Facultad de Ciencias de la Administración de la Universidad Autónoma de

E-mail: Chiapas.ana.nunez@unach.mx

\begin{abstract}
This research took place at CAMASC, SDIF, shelter, Tapachula in Chiapas during 2019-2020. The general objective was to identify and explain motivational strategies used by English teachers for improving motivation. The participants were 17 out of 28 boys and girls with an age range 6-17 years old. The study followed a mixed approach method, qualitative and quantitative. The instruments used were interviews and surveys for teachers, managers, and children. The research questions were: What motivational macro-strategies are most frequently used to motivate children when teaching English at CAMASC SDIF shelter? How are children at "CAMASC" shelter motivated to learn English. The results illustrate which macro-strategies were used more and which ones were used less in the context of this research. This research evidences the importance of developing language teachers' awareness on how to motivate students and work with motivational strategies in the English classroom. It also evidences the need for adequate training for both teachers and trainees.
\end{abstract}

Keywords: motivation, macro-strategies, teach, English, SDIF. 


\section{INTRODUCTION}

This research was performed as part of a university program called UVD (Unidad de vinculación docente), which is a program aiming at providing service to the community, in this case the teaching of English at the Mexican shelter. A motivational problem was identified in the shelter, consequently a need to find a way to motivate students arose. Therefore, in this research motivational macro-strategies used at the SDIF will be identified and ranked. Each ranking will contain the explanations for its usage to make teacher trainees aware of the different variety of strategies available for them to use and the need to train teachers in competences such as technological due to the educational virtuality and the need to use different tools for teaching. In fact, one of the proposals to increase motivation is to give English teachers and trainees conferences about the importance of using motivational strategies in language learning and teaching either in a social service class, congress, symposium, or forum. Once the language teachers raise awareness about the existence of motivation strategies, they will hopefully start using them consciously and more frequently. Therefore, the problem of lack of motivation will be decreased and solved, therefore, the learning goals will be accomplished within a pleasant classroom climate.

\section{METHODOLOGY}

The study follows a mixed method approach, which follows both qualitative and quantitative. This method will help to comprehend the motivational phenomenon at CAMASC SDIF shelter by gathering information from teachers' and students' points of view and a satisfaction survey to administrators. This methodology also helps to describe children's and teachers' motivations, thoughts and attitudes which will help to answer the research questions. The teaching period considered for this research were four months in 2019 (September to December 2019) and two months in 2020 (January-February). The surveys were applied in 2020. The sample for this study is representative of the entire population since 17 out of the 28 children are considered in the study being: 7 children between 7-12 years old, 7 children between 13-17 years old and 3 children between 3-6 years old, two managers (each one from different election years) and 7 teachers. Some ethical issues were considered in this research such as asking for the tutors' consent. The main objective is to identify and explain motivational strategies used by English teachers in relation to the use, planning and selection of tools and to promote motivation when teaching English at CAMASC SDIF shelter, Tapachula.

\subsection{MOTIVATION}

It is known that motivation plays an important role in English Language Teaching and learning and either a child or an adult can learn in an easy way. Motivation is important in the class because all activities that are used and applied during the classes should motivate students to continue learning. 
Broussard and Garrison (2004) defined motivation as the attribute that moves us to do or not to do something (p. 106). Motivation plays an important role in foreign language learning. Besides, when learning motivation is once formed, the students will use an active learning attitude to learn, and express a keen interest in learning, students are able to focus attention on class to learn or master knowledge.

Motivation is a key factor for explaining the success or failure of any difficult activity. It is well known that the success in a task is since someone is motivated. It is easy in second language learning to state that a learner will be successful with the right motivation, (Alizadeth 2016:1)

Al-Otaibi (2004) declared that motivated learners spend much of their time to gain aims in learning foreign language and motivated learners can also learn language more effectively than unmotivated ones.

\subsection{MOTIVATIONAL STRATEGIES IN THE LANGUAGE CLASSROOM}

As Zoltan Dörnyei (2001) mentioned motivational strategies are techniques that promote the individual's goal-related behavior and refer to those motivational influences that are consciously exerted to achieve some systematic and enduring positive effect. In addition to that, motivational strategies are tactics, techniques, or approaches to encourage learners or students to participate in the teaching and learning process (Rasmussen, K. 2008).

Katyshev Pavel, Leshutina Irina, Elnikova Svetlana (2020) considered motivational strategies as processes, methods, means of encouraging students to productive cognitive activity, to actively master the educational material and depending both on the actions of the teacher and the student himself.

From the definitions above, we consider that motivational strategies are necessary means to achieve effectively teaching and learning inside the classroom and promote a positive effect during the English learning-teaching process.

Dörnyei is one of the most important scholars who have studies in the area of motivational strategies and he favors the use of an educational application model because he considers it to be more comprehensive to be used during the teaching practice. He considers four main motivational aspects for adequate teaching practice: Generating initial motivation, maintaining, and protecting motivation, encouraging positive retrospective self-evaluation and creating the basic motivational conditions.

\section{ANALYSIS OF RESULTS}

The results of the instrument implemented for identifying the ten motivational macro-strategies used at CAMASC, SDIF shelter included 48 motivational strategies and are presented below with valuable information which was used to determine the frequent use of each one and the reasons for applying one or another. The analysis of results helped to answer research question one about the motivational macrostrategies used to motivate children when teaching English at CAMASC SDIF shelter. 
Table 6. Final macro-strategies rank order results at CAMASC SDIF shelter

\begin{tabular}{|l|c|}
\hline Motivational strategies ranking order at SDIF Tapachula & Ranking \\
\hline Proper teacher behavior & 2 \\
\hline Recognize students' effort & 4 \\
\hline Promote learners' self-confidence & 5 \\
\hline Creating a pleasant classroom climate & 3 \\
\hline Present tasks properly & 8 \\
\hline Increase learners' goal-orientedness & 6 \\
\hline Make the learning tasks stimulating & 9 \\
\hline Familiarize learners with L2-related values & 7 \\
\hline Promote group cohesiveness and group norms & 10 \\
\hline Promote learner autonomy & \\
\hline
\end{tabular}

The table above summarizes the results and illustrates which macro-strategies were used more and which ones were used less in the context of this research, being number one the most frequently used and number ten the least frequently used. The motivational strategy used the most was "proper teacher behavior" and the least one used was "promote learner autonomy"

Proper teacher behavior. Appropriate teacher behavior was seen as the most important motivational macro-strategy in the SDIF, Tapachula. Moreover, the same macro-strategy was found as number one in Taiwan (Cheng \& Dörnyei, 2007) and in Hungary (Dörnyei \& Csizer, 1998). It is relevant to emphasize the fact that the same finding emerged from three very different contexts which see this macro-strategy as the most powerful tool according to teachers' points of view and it confirms the importance of developing enthusiasm for the subject through positive teachers' aptitudes and attitudes.

Recognize students' effort. The importance of recognizing student's effort macro-strategy was ranked in second. The reason for this is because it is important for the student to feel worthy. The teacher should recognize and congratulate students' effort and progress. The teacher should be a support for the students' learning and progress inside and outside the class and encourage them all the time.

Present tasks properly were ranked as the third macro-strategy mostly used. This study reveals that motivation can be affected either in a positive or negative way due to the appropriate or inappropriate use of tasks, no matter how good the teacher is, if the teacher does not select the right activities for them, the students will not be motivated. It is perceived that the way the teacher presents the learning tasks bears a strong effect on the teaching-learning process.

Promote learners' self-confidence. This macro-strategy was ranked as fourth. Developing the cando-spirit in students has always been vital because it has always been accepted in educational psychology that the way students perceive or judge their own ability directly affects their willingness to complete a task. Teachers at the SDIF were conscious of the importance of this macro-strategy because of the children's vulnerable context. Therefore, they tried to develop it in different ways to increase their selfconfidence and gain resilience. 
Creating a pleasant classroom climate was ranked in the fifth place at the SDIF, Tapachula. Teachers are convinced of the positive benefits on learners' motivation because the classroom must be a safe and pleasant place for learning, sharing, and commenting opinions. Besides, children love the classroom when the teaching-learning atmosphere is in a well-developed manner and even when they make mistakes.

Make the learning tasks stimulating. This macro-strategy was ranked as number sixth. The teachers who answered this survey considered the importance of making each task stimulating. Teachers at the SDIF achieved this by selecting appropriate activities according to students' ages and needs to increase motivation. From our experience, there could be some bad consequences in case teachers do not put this macro-strategy into practice such as: lack of students' participation and attention, poor motivation and not completing the assigned tasks.

Promote group cohesiveness and group norms. The survey indicates that this macro-strategy was ranked as the seventh place. Promoting group rules at the beginning of the course was important for SDIF teachers because it helped them to achieve a good classroom management. It is important to include a proper negotiation when establishing the rules and the consequences. Furthermore, to achieve good cohesiveness, it is crucial to reinforce tolerance and respect between the students.

Increase learners' goal-orientedness was ranked in the eighth place. In this particular context, it was difficult to implement this macro-strategy because the English course was within the informal educational pedagogy. Informal education does not give grades, diplomas or certificates endorsed by the SEP (Secretaría de Educación Pública) or the British Council. Therefore, instrumental, and goal-oriented motivation were not considered necessary at SDIF, Tapachula.

Familiarize learners with L2-related values. The results place this strategy as the ninth one used at the SDIF, Tapachula. It can be inferred that teachers are probably not aware of the importance of developing intercultural competence. As stated, “Over the past decades raising L2 learners' cross-cultural awareness has become a key objective in several language programs across the world" (Cheng \& Dornyei, 2007:163).

It was observed that children at CAMASC SDIF shelter did not come from an ethnic origin during the period of this research. Most teachers introduced a few cultural topics such as: the day of the death, Halloween, Easter, and Christmas. These topics covered some cultural aspects and comparisons between the Mexican and the American cultures. However, teachers manifested that they did not reinforce students' cultural identity such as: reinforcing feeling proud of themselves, traditions, developing tolerance and respect of other cultures. 
Another problem teachers faced was the fact that children at the SDIF are not allowed to leave the shelter, therefore, it was impossible encourage students to use the language outside the classroom or to invite an English speaker into the shelter because of the extensive permission process.

Promote learner autonomy was ranked as the tenth macro-strategy used at CAMASC SDIF, Tapachula. It was perceived that not all English teachers were ready to implement learners' autonomy in class, even when they adopted the facilitator role. Although teachers' opinions pointed out that promoting intrinsic motivation was important, they were not able to develop it at the SDIF shelter. Some of the reasons for these might be lack of time, children's misbehavior, lack of teachers' awareness. Teachers also mentioned that it was difficult to develop intrinsic motivation at a very young age. It implies that English teachers were not ready to take off the 'authoritarian' mask and let learners govern their own learning process.

In relation to teachers' opinions, seven teachers were interviewed to respond question two: How are children at "CAMASC" shelter motivated to learn English?

There are two points of view (students' and teachers') related to the factors found which motivate students to learn English at CAMASC SDIF shelter. The first one considered teachers' point of view since they mention factors such as good planning of lessons with a good selection of activities which matches students' interests and likes. They also mentioned that the use of songs and ludic activities are totally positive and useful when referring to the development of motivation in children.

According to teachers' interview, songs and ludic activities are totally useful because children love singing and dancing. Songs make children learn, memorize, reinforce, and practice pronunciation of English words.

As teacher A mentions "Music and songs have a positive effect in students because it helps establish a secure learning environment and it contextualizes the topic." Besides, teacher A states that "Songs are catchy for students and the rhythm helps them memorize words and phrases" which are useful in real life. Moreover, teacher B, C and D agreed that songs can help children learn and memorize English words easily. Teacher E ensures that "It is very important since everyone likes songs, adults, children, teenagers" and" it is a fact that not only children learn by listening to songs". Furthermore, teacher F said "I think it is important because they learn vocabulary, pronunciation and get motivated to learn more. It is also a good strategy so they can learn, practice and remember." (December 15 ${ }^{\text {th }}, 2019$ )

Besides, according to the children's survey, in relation to the way they like learning English, they answered that they prefer learning English when a combination of factors and strategies are used instead of using only one way of teaching as it is exemplified in question 2 of students' survey with an $82.4 \%$ such as the use of songs, images, games, and kinesthetic activities. They also answered to prefer learning English with group or team activities instead of working individually by themselves. 
According to teachers' interview, the development of students' intrinsic motivation is essential since students are curious, willing to learn more, develop autonomy, love for the things they do.

According to the teachers' interview, intrinsic motivation leads to some beneficial factors: a) the development of curiosity, b) the feeling of belonging to a group, c) students interests' awareness, d) value awareness, e) self-confidence towards achieving activities and goals, and f) empathy on the part of the children. In other words, students would feel welcome and in a secure place, would feel excited and safe to be part of the class when they perceive the teacher is interested in each child and gives them a feeling of care.

On the other hand, the use of extrinsic motivation is recommended with toddlers and young children as shown in teachers' interview, because they like rewards such as candies, prizes, or points. However, it is important to little by little move from extrinsic to intrinsic motivation to help students develop a sense of awareness of their own learning.

\section{PROPOSAL AND RECOMMENDATIONS}

Some recommendations for teachers are to adopt the role of a facilitator, to encourage peer teaching and group presentations, to teach self-motivating strategies, and to allow students to assess themselves. Teachers who become facilitators are supportive, comprehensive, caring and serve as scaffolders. Again, teachers should consider the use of motivational strategies as part of their pedagogical practice when developing the five skills and abilities such as cognitive, speaking, affective or emotional, social, fine, and gross motor skills which will help students become successful adults. (Scott and Ytreberg (1991) in Bermejo et al (2019:22). We believe, that if each student can develop these skills in class, they will also be motivated because they will acquire competencies which will help them in their future life.

It is important to remember this well-known Chinese saying, "If you give a man a fish, he will have a single meal, but if you teach a man to fish, he will eat his whole life". This applies for teachers to remember that it is important for students to do the things by themselves, to become autonomous, critical, and responsible.

\section{CONCLUSION}

In light of the above, implementing the forty-eight motivational strategies will definitely help increase motivation in the language classroom. Nevertheless, not even the most experienced teachers can use all of them at the same time or in a single class. Thus, it is recommendable to select a few of them for a specific class since quality is much better than quantity. The important thing is that the teacher should always be reflective, critical, and willing to improve. 
Truly, a good language teacher motivator is not the one that reaches the highest motivation in students only in one class, on the contrary, it is the one who reflects, selects, varies and is willing to take risks to keep their students motivated through motivating activities and adequate tools according to their students' ages and needs.

In addition, it is also important to be aware that some macro-strategies are universal across cultures and ethnic linguistic contexts, for instance, proper teacher behaviour, promoting learner's self-confidence, creating a pleasant classroom climate, and presenting tasks properly. Interestingly, all of the strategies previously mentioned were ranked as the most highly used at the SDIF, Tapachula, whereas the macrostrategies which are culturally dependent were ranked as the two least used at the SDIF as is the case of: 'promoting learner's autonomy' and 'familiarize learners with L2 related values'. These two macrostrategies can or cannot be important to be developed depending on the context or culture. For example, at the SDIF, the students manifested their need to become independent and autonomous due to the parental absence. In other cultures, such as the Asian or Japanese, it is difficult to work with cultural dependent macro-strategies, and ludic activities that promote autonomy because of their culture and community values. 


\section{REFERENCES}

Al-Hazemi, H. (2000). Lexical Attrition of Some Arabic Speakers of English as a Foreign Language: a Study of Word Loss. Internet TESL J [Serial online] Available from: http://iteslj.org/Articles/Al-HazemiAttrition/

Alizadeh I. (2016). Vocabulary Teaching Techniques: A Review of Common Practices. IJREE. 2016; 1 (1) from: http://ijreeonline.com/article-1-25-en.html

Al-Otaibi, G. (2004). Language Learning Strategy Use among Saudi EFL Students and Its Relationship to Language Proficiency Level, Gender, and Motivation [PhD Dissertation]. Indiana (PA): Indiana University of Pennsylvania.

Broussard, S. C., \& Garrison, M. E. B. (2004). The Relationship between Classroom Motivation and Academic Achievement in Elementary School-aged Children. Family and Consumer Sciences Research Journal, 33(2), 106-120.

Cheng, H. \& Dornyei, Z. (2007). The Use of Motivational Strategies in Language Institution: The case of EFL teaching in Taiwan. Innovation in Language Learning and Teaching, 1(1) pags. 153 - 174. Retrieved from: https://www.yumpu.com/en/document/read/52482499/the-use-of-motivational-strategies-inlanguage-instruction-the-State University).

Dörnyei, Z. (1998). Conceptualizing Motivation in Foreign Language Learning. Language Learning, 40, 46-78, 1998.

Dörnyei, Z. (2001). Motivational strategies in the language classroom. Cambridge, UK: Cambridge University Press. https://doi.org/10.1017/CBO9780511667343.

Katyshev Pavel, Leshutina Irina, Elnikova Svetlana (2020). Modern educational strategies for the training of philologists in higher education. Moldova: IGI Global.

Rasmussen, K. and Nichols, J. (2008). Case Studies in Virtual Multicultural Education. Florida: IGI Global. 


\section{NOTAS BIOGRÁFICAS}

La Dra. Gloria Amelia Gutu Moguel, concluyó el Doctorado en Educación por el Instituto de Estudios Superiores de Chiapas, Maestría en Enseñanza del Inglés por la Universidad de Southampton, Reino Unido, Maestría en Docencia por la UNID, y Licenciatura en Enseñanza de Inglés por la Universidad Autónoma de Chiapas (UNACH). Profesora de Tiempo Completo, perfil PRODEP en la UNACH es Coordinadora de Investigación y Posgrado de la Escuela de Lenguas, Tapachula, Campus IV. En el ámbito académico se ha desempeñado como docente e investigadora de la Licenciatura en la Enseñanza del Inglés, modalidad presencial y es Coordinadora de los trabajos de Diseño e Implementación de la Maestría en Enseñanza del Inglés y de la Academia de Lingüística de la Escuela de Lenguas, de la UNACH, Campus IV. Ha publicado artículos sobre plagio y enseñanza de lenguas extranjeras.

C. Eric Iván Aguilar Salvador, concluyó la Licenciatura en Enseñanza del Inglés en la Universidad Autónoma de Chiapas (UNACH). Ha impartido clases de inglés en el nivel básico incluyendo preescolar, primaria y secundaria. También es profesor independiente impartiendo clases de ESP.

C. José Antonio Aguilar Salvador, actualmente cursa el noveno semestre de la Licenciatura en la Enseñanza del Inglés de la Escuela de Lenguas de la UNACH. Ha impartido clases de manera independiente y usa la creatividad para el diseño e implementación de materiales didácticos.

La Mtra. Angélica Patricia Córdoba Meza concluyó la Maestría en Educación en Desarrollo de Formadores (ELT), por la Universidad de Exeter, Inglaterra, la Especialidad en la Enseñanza de Inglés por la Universidad Autónoma de Yucatán (UADY), y la Licenciatura en Lengua Inglesa por la Universidad Veracruzana. En su vida académica de más de 25 años ha sido catedrática de Tiempo Completo, en la Escuela de Lenguas, Campus IV, de la Universidad Autónoma de Chiapas, donde ha impartido clases en los programas educativos de la Licenciatura en la Enseñanza del Inglés, la Licenciatura en inglés, modalidad a distancia, y el Departamento de Lenguas.

La Dra. Antonia Jiménez Alba concluyó el Doctorado en Educación por el Instituto de Estudios Superiores de Chiapas, Meza concluyó la Maestría en Educación en Desarrollo de Formadores (ELT), por la Universidad de Exeter, Inglaterra, y la Licenciatura en Lengua Inglesa y Francesa por la Universidad Veracruzana. Tiene una vida académica de más de 25 años ha sido catedrática de Tiempo Completo, en la Escuela de Lenguas, Campus IV, de la Universidad Autónoma de Chiapas, donde ha impartido clases de inglés y francés en los programas educativos de la Licenciatura en la Enseñanza del Inglés.

La Dra. Ana Rosa Núñez Serrano, concluyó el Doctorado en Educación por el Instituto de Estudios Superiores de Chiapas (IESCH), Maestría en Dirección Ejecutiva por la UNACH, es pedagoga y Licenciada en Derecho por el (IESCH). Ha sido coordinadora del Programa de Acción Tutoría, consejera técnica. Actualmente es catedrática de la Universidad Autónoma de Chiapas y cuenta con una especialidad en Derechos Humanos. 